\title{
Effect of calcium lactate concentrations on post-harvest storage life of apple fruit
}

\author{
Altaf Ur Rehman ${ }^{1}$, Asad Ali ${ }^{1}$, Alif Khan ${ }^{1}$, Abdul Qayum ${ }^{1}$, Ziaur \\ Rahman $^{2 *}$, Hassan Waqas ${ }^{1}$ and Zaka Ur Rehman ${ }^{1}$ \\ 1. Department of Food Science \& Technology, The University of Agriculture, Peshawar-Pakistan \\ 2. Department of Agriculture, The University of Swabi, Swabi-Pakistan \\ *Corresponding author's email: zia@uoswabi.edu.pk \\ Citation
}

Altaf Ur Rehman, Asad Ali, Alif Khan, Abdul Qayum, Ziaur Rahman, Hassan Waqas and Zaka Ur Rehman. Effect of calcium lactate concentrations on post-harvest storage life of apple fruit. Pure and Applied Biology. Vol. 6, Issue 4, pp13401344. http://dx.doi.org/10.19045/bspab.2017.600144

\begin{tabular}{llll}
\hline \hline Received: 19/06/2017 & Revised: 09/10/2017 & Accepted: 12/10/2017 & Online First: 26/10/2017 \\
\hline
\end{tabular}

\section{Abstract}

The current study was carried out to check the effect of dissimilarity of calcium lactate concentrates on post-harvest life of apple fruit during storage. The treatments included $\mathrm{A}_{\mathrm{o}}$ (control), $\mathrm{ACaLa} 1(01 \%), \mathrm{ACaLa}_{2}(02 \%)$ and $\mathrm{ACaLa} 3(03 \%)$ respectively during storage at ambient temperature on the shelf life of apple fruit after harvesting. All the samples including control and treated samples were filled in flexible box and were investigated for physicochemical features (total soluble solid, $\mathrm{pH}$, titratable acidity and decay index). The above mentioned quality parameters of whole apple fruits influenced treatments and storage. Storage outcome shown that increased in TSS was found from (12.13 to $\left.14.31{ }^{\circ} \mathrm{Brix}\right), \mathrm{pH}$ from (4.05 to 5.21), decay index from (0 to 44.14$)$ during 3 months of storage. In control sample (4.47) highest mean value for $\mathrm{pH}$ was observed, while treatment CaLa $2 \%$ (4.30) was found minimum. Declining in treatment during storage was found in the following parameters Acidity and overall acceptability. The treatment CaLa $2 \%$ has shown the best result while showing maximum stability in physicochemical qualities of the fruit followed by $\mathrm{CaLa} 1 \%$ and CaLa $3 \%$ respectively.

Keywords: Apple; Calcium lactate; Decay index; Post-harvest; TSS; pH; Titratable acidity

\section{Introduction}

Apple fit in to the family Rosaceae, its botanical name is (Pyrus malus). It is an imperative fruit and is approximately enjoyed all over the word by all standards of the people due to its dietetic and costeffective significance. Apple are cultivated in KPK, Punjab and Baluchistan. The primary habitat of the apple is measured to be in the Southwest Asia nation, as well as the state of Israel. From there it proliferates to Europe and the whole world. Apples can cultivate anywhere, very warm otherwise in chilly environment [1]. In Pakistan the cultivation of apple was 105.2 thousand hectares which include Punjab, KPK,
Baluchistan and Sind $(0.4,8.1,96.7$ and $0.1)$ thousands hectares although in Pakistan whole production was 606.1 thousand tons which include 92.3 in KPK, 3.6 Punjab, 510.2 in Baluchistan and 3.6 in Sindh [2]. Apple contains 0.3g ash, Vitamin C $8 \mathrm{mg}, 0.3 \mathrm{~g}$ lipid, $13.9 \mathrm{~g}$ carbohydrates, $0.4 \mathrm{~g}$ proteins, $0.8 \mathrm{~g}$ fiber, $84.7 \%$ water, and edible portion of apple contain $57 \mathrm{~K}$ cal of energy per $100 \mathrm{~g}$ [3]. Apple contains total minerals $0.3 \mathrm{~g} / 100 \mathrm{~g}$. In which magnesium $6 \mathrm{mg} / 100 \mathrm{~g}$, calcium $7 \mathrm{mg} / 100 \mathrm{~g}$, potassium $145 \mathrm{mg} / 100 \mathrm{~g}$, sodium $0.3 \mathrm{mg} / 100 \mathrm{~g}$, iron $480 \mathrm{ug} / 100 \mathrm{~g}$, phosphorus $12 \mathrm{mg}$ and iodine $2 \mathrm{ug}$ are present [4]. 
Apple is well-liked because of the many ways that they can be consumed and because of their ease and stability. Apples may be consumed off the tree or stored for up to a full year. It can be processed into sauce, juice, slices, and are favored for cakes, tarts, pastries, and pies [5]. Mineral exist in Ash when food is creamed, having 2 main functions, building and regulation in the body. The adjustment of water content in the body Sodium is necessary while several enzymes activated through magnesium. Potassium adjusts osmotic pressure of the cell contents and $\mathrm{pH}$. For the development of bones and teeth calcium is important. An inherent iron transported oxygen from the lungs to muscles and other parts of the body [3]. Initially apple was used broadly as a food and was also famous for its remedial characteristics. For the purpose of intestinal disorders such as dysentery and diarrhea of 10infant apple was used [6]. In Pakistan apple was used in fresh mode and the production of apple was excessive, became plentiful in the market but lack of storage facilities\& perishable nature resulted serious losses. The main objective of this research work was to study the effect of Calcium lactate on the post-harvest life of apple fruit at room temperature.

\section{Materials and methods}

This research was accomplished at Pakistan Council of Scientific \& Industrial Research (PCSIR) in the Quality control lab of Food processing, Peshawar, Khyber Pakhtunkhwa, Pakistan. The fruits of apple were purchased from the local market of Peshawar. The variety selected for this research was Kaja variety (Green in color). The fruit selected for this experiment was proper mature not fully ripe and have the ability to support strength during storage. Total number of fruit selected for this experiment was 160 . These fruit were then divided into four lots. Each lot contains 40 no of fruits. Lot no 1. Stands for $\left(A_{0}\right)$ control without the use of calcium lactate. Lot no 2. Stands for (ACaLa 1) with the use of calcium lactate $1 \%$. Lot no 3 . Stands for (ACaLa2) with the use of calcium lactate $2 \%$. Lot no 4. Stands for (ACaLa3) with the use of calcium lactate $3 \%$ respectively. The fruits were then immersed in each lot containing water and calcium lactate for five minutes. The fruits were then take out from each lot and dried under the fan (Table 1).

Table 1. Study plan

\begin{tabular}{|c|c|c|c|}
\hline S. No. & Samples & Preservatives & Ratio \\
\hline 1 & $\mathrm{~A}_{\circ}$ & Untreated fruits & - \\
\hline 2 & $\mathrm{ACaLa} 1$ & Ca lactate & $1 \%$ \\
\hline 3 & $\mathrm{ACaLa} 2$ & Ca lactate & $2 \%$ \\
\hline 4 & $\mathrm{ACaLa} 3$ & Ca lactate & $3 \%$ \\
\hline
\end{tabular}

After the putting of the above mentioned lots apple in soft carton as per procedure of [7]. The examination was initiated on the first day of the experiment and was continued after 10 days interval i.e. ( day 0 , day 10, day 20 , day 30 , day 40 , day 50 , day 60 , day 70 ) until the apples were found unacceptable for further research due to spoilage.

\section{Physicochemical analysis pH}

All test of $\mathrm{pH}$ was noted by $\mathrm{pH}$ meter the digital one that is (Milwankee Brand Model No. 22: 17-40) as illustrate in standard method of AOAC [8]. Firstly turned on the $\mathrm{pH}$ meter and was in distinguishable with $\mathrm{pH}$ 4 and 7 buffer solution. The electrodes was washed with refined water and dehydrated with tissue paper prior to determine the sample $\mathrm{pH}$.

\section{Total soluble solids (TSS)}

The TSS was precisely recorded by digital Refractometer (Atago Rx-1000) as reported by AOAC [8]. TSS of the samples was resolved accordingly the mention technique for AOAC (2012). For this reason digital Refractometer was utilized. Through 
distilled water the prism of Refractometer was washed and then dried with tissue paper. After this sample was put on the prism held up until to get fix information.

Acidity (\%)

The; acidity was determined by means of standard methods (Method, 942.15) present in of AOAC [8].

The pulp of apple was pulverized and then takes 10 gram of this pulp and makes a volume of diluted juice up to $100 \mathrm{ml}$ by utilizing distilled water. After this $10 \mathrm{ml}$ of juice was taken from that diluted juice with the addition of 1-2 drops of phenolphthalein indicator and was titrated against $0.1 \mathrm{~N}$ $\mathrm{NaOH}$ in anticipation of pink color appeared. The formula used for acidity determination is mentioned as under:

Acidity $(\%)=\frac{\text { C.F x N x T x D x } 100}{\text { V x S }}$

\section{Ascorbic acids}

Vitamin $\mathrm{C}$ was explain by the method of titration as suggested by of AOAC [8]. First of all dye solution was prepared and standardized then standard ascorbic acid solution was prepared and oxalic acid solution. After this, standardization of dye took place and then the sample was titrated. The following formula was used to calculate the ascorbic acids contents:

Ascorbic acid $(\mathrm{mg} / 100 \mathrm{~g})=\frac{\mathrm{v} \times \mathrm{F} \times 150 \times 10}{\mathrm{D} \times \mathrm{P}}$

\section{Decay index (\%)}

Decay index of apple samples were recorded as illustrate by Wang et al. [9].

Decay index $(\%)=(1 \times \mathrm{N} 1+2 \times \mathrm{N} 2+3 \times \mathrm{N} 3) \times 1$ $00 /(3 \times N)$

\section{Statistical Analysis}

The data was examined statistically by utilizing Complete Randomized Design (CRD) Two Factorial and means were separated by LSD test at $5 \%$ level of significance as described by Steel and Torrie [10].

\section{Results and discussion}

\section{Physico-chemical properties pH}

Firstly the $\mathrm{pH}$ content of samples (control to CaLa 3\%) was $4.05,4.05,4.06$, and 4.05 which was slowly increased to 5.42, 5.36, 4.66, and 5.41 in that order throughout storage (Table 2). $\mathrm{pH}$ content of mean value significantly $(\mathrm{p}<0.05)$ increase from 4.05 to 5.21 in research. For treatment highest values for mean were observed in control treatment (4.47) followed by CaLa 3\% (4.43), while average values for mean were noted in treatment $\mathrm{CaLa} 2 \%$ (4.30) followed by $\mathrm{CaLa} 3 \%$ (4.42). Highest inclined was noted in control sample (25.28\%) followed by CaLa 1\% (24.44\%) whereas smallest increase was found into treatment CaLa 2\% (12.87\%) followed by CaLa 3\% (25.14) respectively. These results are in conformity with the decision of Ball [11] who recorded an increase in $\mathrm{pH}$. The increase in $\mathrm{PH}$ is due to the conversion of sugars to acid during respiration process.

\section{Total Soluble Solids (TSS)}

Treatment of TSS (Control to CaLa 3\%) on the first day was $12.2,12.1,12.1$, and $12.1^{\circ}$ brix, inclined to $14.72,13.87,13.84$, and $14.8{ }^{\circ}$ brix correspondingly during 70 days storage (Table 3). For treatment highest mean was noted in control treatment (13.63) followed by CaLa 3\% (13.36) ${ }^{\circ}$ brix, whereas minimum values for mean were observed in CaLa 2\% (13.17) followed by CaLa 1\% (13.20). In research highest increase was observed in CaLa 3\% (18.24) whereas decline was recorded in treatment CaLa 2\% (12.57) ${ }^{\circ}$ brix correspondingly.

\section{Decay index $(\%)$}

Initially all the samples of decay index was zero which was slowly inclined to 55.72, 39.66, 40.67, and 40.50 correspondingly during research (Table 4). For treatment greatest values for mean was noted in control treatment (26.03) followed by CaLa $3 \%$ (17.74), whereas smallest values for mean were founded in treatment CaLa $2 \%$ (16.61). In research highest inclined were observed into A0 sample (55.720, while minimum was observed in CaLa $2 \%$ (39.66). The outcome of this research are in secure similarity to that of Kohli [12] who initiated the connection of $\mathrm{Ca}$ ion with the ingredient of cell which motivate Ca reliant 
enzymes during leakage that carry strength in tissues and lower the fruits decay rate.

\section{Percent acidity}

First of all the samples of acidity was 0.91, $0.88,0.92$, and 0.9 which were fall down to $0.56,0.56,0.63$ and 0.58 correspondingly in the research (Table 5). For treatment greatest values for mean were noted into
CaLa 2\% treatment (0.78) followed by CaLa 3\% (17.74), whereas smallest values for mean were found in control treatment (0.72). A declined was recorded in control sample (38.46), while lowest was observed in CaLa 2\% (31.52). These outcomes are in close resemblances with the judgment of [13].

Table 2. Effect of calcium lactate concentrations \&storage intervals on $\mathrm{pH}$ of apple fruits

\begin{tabular}{|c|c|c|c|c|c|c|c|c|c|c|}
\hline \multirow{3}{*}{ Treatment } & \multicolumn{8}{|c|}{ Storage interval (days) } & \multirow{3}{*}{$\%$ inc } & \multirow{3}{*}{ Mean } \\
\hline & Control & 10 & 20 & 30 & 40 & 50 & 60 & 70 & & \\
\hline & \multicolumn{8}{|c|}{ pH } & & \\
\hline Control & 04.05 & 04.06 & 04.08 & 4.34 & 04.18 & 04.36 & 05.28 & 5.42 & $25.28 \%$ & $04.47 a$ \\
\hline CaLa (1\%) & 04.05 & 04.07 & 04.08 & 4.14 & 04.18 & 04.33 & 05.26 & 5.36 & $24.44 \%$ & 04.43ab \\
\hline $\mathrm{CaLa}(2 \%)$ & 04.06 & 04.09 & 04.12 & 4.17 & 04.28 & 04.48 & 04.51 & 4.66 & $12.87 \%$ & $04.30 \mathrm{c}$ \\
\hline $\mathrm{CaLa}(3 \%)$ & 04.05 & 04.07 & 04.2 & 4.16 & 04.01 & 04.25 & 05.01 & 5.41 & $25.14 \%$ & $04.42 b$ \\
\hline Mean & 04.05f & 04.07f & 04.12ef & 04.20d & 04.19de & $04.36 \mathrm{c}$ & 05.04b & $05.21 \mathrm{a}$ & & \\
\hline
\end{tabular}

Values followed by different letters are significantly $(\mathrm{p}<0.05)$ different from each other

Table 3. Effect of calcium lactate concentrations \& storage intervals on TSS of apple fruits

\begin{tabular}{|c|c|c|c|c|c|c|c|c|c|c|}
\hline \multirow{3}{*}{ Treatment } & \multicolumn{8}{|c|}{ Storage interval days } & \multirow{3}{*}{$\%$ Inc } & \multirow{3}{*}{ Mean } \\
\hline & initial & 10 & 20 & 30 & 40 & 50 & 60 & 70 & & \\
\hline & \multicolumn{8}{|c|}{ TSS $^{\circ}$ Brix } & & \\
\hline Control & 12.2 & 12.9 & 13.17 & 13.18 & 14.21 & 14.29 & 14.35 & 14.72 & $17.11 \%$ & $13.63 \mathrm{a}$ \\
\hline $\mathrm{CaLa}(1 \%)$ & 12.1 & 12.58 & 12.88 & 13.27 & 13.52 & 13.63 & 13.74 & 13.87 & $12.76 \%$ & $13.20 \mathrm{c}$ \\
\hline $\mathrm{CaLa}(2 \%)$ & 12.1 & 12.56 & 12.82 & 13.25 & 13.5 & 13.6 & 13.72 & 13.84 & $12.57 \%$ & $13.17 \mathrm{c}$ \\
\hline $\mathrm{CaLa}(3 \%)$ & 12.1 & 12.6 & 12.78 & 12.88 & 13.4 & 13.6 & 14.72 & 14.8 & $18.24 \%$ & $13.36 \mathrm{~b}$ \\
\hline Mean & 12.13h & $12.66 \mathrm{~g}$ & 12.91f & $13.15 \mathrm{e}$ & 13.66d & $13.78 \mathrm{c}$ & 14.13b & $14.31 \mathrm{a}$ & & \\
\hline
\end{tabular}

Values followed by different letters are significantly $(\mathrm{p}<0.05)$ different from each other

Table 4. Effect of calcium lactate concentrations \& storage intervals on decay index of apple fruits

\begin{tabular}{|c|c|c|c|c|c|c|c|c|c|c|}
\hline \multirow{3}{*}{ Treatment } & & & 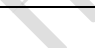 & Storage & terval (d & & & & \multirow{3}{*}{$\%$ Inc } & \multirow{3}{*}{ Mean } \\
\hline & Control & 10 & 20 & 30 & 40 & 50 & 60 & 70 & & \\
\hline & \multicolumn{8}{|c|}{ Decay index } & & \\
\hline Control & 0 & 4.26 & 13.08 & 22.69 & 25.12 & 38.25 & 48.41 & 55.72 & $55.72 \%$ & $26.03 a$ \\
\hline $\mathrm{Ca} \mathrm{La}(1 \%)$ & 0 & 3.04 & 8.02 & 12.42 & 15.16 & 28.50 & 33.34 & 39.66 & $39.66 \%$ & 17.52b \\
\hline $\mathrm{Ca} \mathrm{La}(2 \%)$ & 0 & 3.18 & 8.39 & 11.60 & 14.80 & 25.60 & 28.67 & 40.67 & $40.67 \%$ & $16.61 b$ \\
\hline $\mathrm{Ca} \mathrm{La}(3 \%)$ & 0 & 3.25 & 7.80 & 13.70 & 15.60 & 24.60 & 36.50 & 40.50 & $40.50 \%$ & 17.74b \\
\hline Mean & $\mathbf{0 h}$ & $3.43 \mathrm{~g}$ & $9.50 \mathrm{f}$ & $15.10 \mathrm{e}$ & 17.67d & $29.24 c$ & 36.73b & $44.14 a$ & & \\
\hline
\end{tabular}

Values followed by different letters are significantly $(\mathrm{p}<0.05)$ different from each other

Table 5. Effect of calcium lactate concentrations \& storage intervals on acidity of apple fruits

\begin{tabular}{|c|c|c|c|c|c|c|c|c|c|c|}
\hline \multirow{3}{*}{ Treatment } & \multicolumn{8}{|c|}{ Storage interval (days) } & \multirow{3}{*}{$\%$ Dec } & \multirow{3}{*}{ Mean } \\
\hline & Control & 10 & 20 & 30 & 40 & 50 & 60 & 70 & & \\
\hline & \multicolumn{8}{|c|}{ Acidity (\%) } & & \\
\hline Control & 0.91 & 0.88 & 0.78 & 0.72 & 0.68 & 0.64 & 0.58 & 0.56 & 38.46 & $0.72 c$ \\
\hline $\mathrm{Ca} \mathrm{La}(1 \%)$ & 0.88 & 0.84 & 0.80 & 0.77 & 0.71 & 0.65 & 0.63 & 0.56 & 36.36 & $0.73 \mathrm{bc}$ \\
\hline $\mathrm{Ca} \mathrm{La}(2 \%)$ & 0.92 & 0.87 & 0.84 & 0.81 & 0.77 & 0.73 & 0.66 & 0.63 & 31.52 & 0.78a \\
\hline CaLa (3\%) & 0.90 & 0.86 & 0.82 & 0.78 & 0.72 & 0.68 & 0.64 & 0.58 & 35.56 & $0.75 b$ \\
\hline Mean & $0.90 a$ & $0.86 b$ & $0.81 c$ & $0.77 d$ & $0.72 \mathrm{e}$ & $0.68 f$ & $0.63 g$ & $0.58 h$ & & \\
\hline
\end{tabular}

Values followed by different letters are significantly $(\mathrm{p}<0.05)$ different from each other 


\section{Conclusion}

In this research the apple fruit were studied during storage of 70 days to increase their shelf life by the use of Calcium lactate at dissimilar proportion like $1 \%, 2 \%, 3 \%$ respectively. The decay index can be accomplished by using $\mathrm{Ca}$ lactate during storage in relation to control. TSS of apple sample increased during storage. In the same way the preserved apples were also approximate for quality, essence, tint, overall adequacy and viewing best product. Instead Ca.lactate (2\%) as kept sensory \& physicochemical quality of apples enhanced than $\mathrm{Ca}$. lactate $(1 \%)$ \& $\mathrm{Ca}$. lactate $(3 \%)$.

\section{Authors' contributions}

Conceived and designed the experiments: A Qayum \& ZU Rehman, Performed the experiments: AF Rehman, Analyzed the data: A Ali, Contributed reagents/ materials/ analysis tools: A Khan \& $\mathrm{H}$ Waqas, Wrote the paper: Z Rahman \& AU Rehman.

\section{References}

1. Chaudhary MI (1994). Fruit crops in horticulture. M.N. Malik. (Editor) $1^{\text {st }}$ Edn. National Book Foundation, Islamabad: 471-473.

2. Agricultural statistic of Pakistan (201314). Govt of Pakisan. Ministry of Food, Agriculture and Livestock, Economic Wing, Islamabad: 92.

3. Hussain T (2001). Food composition table for Pakistan. Govt of Pakistan ministry of P \& D Islamabad.

4. Vieths S, Schoning B \& Jankiewiez A (1993). Occurance of $\operatorname{lgE}$ binding allergens during ripening of apple fruits. Food Agric Immunol 5: 93-105.

5. Rahman MA (2015). Comparative Study between Local and Imported Apple (Malus domestica) Fruits and their Uses in Juice Production. Science International 3(2): 69-72.

6. Considine M (1982). Food and Food production encyclopedia. Van-Nostrand 24(3).

7. Ahmed J, Ramaswamy HS \& Raghavan VG (2007). Dielectric properties of butter in the MW frequency range as affected by salt and temperature. Journal of Food Engineering 82(3): 351-358.

8. AOAC (2012) Official methods of analysis Association of Official and Analytical chemists $17^{\text {th }}$ Edi. Washington, D.C.

9. Wang Y, Tian SP \& Xu Y (2005). Effect of high oxygen concentration on antioxidant enzymes in peach during postharvest periods. J Food Hort Sci 27: 1295-1297.

10. Steel, RGD \& Torrie JH (1977). Principles and procedures of Statistics. Mc. Graw Hill Pub. Co. Inc. New York.

11. Ball JA (1977). Evaluation of two lipid based edible coating for their ability to preserve post-harvest quality of green bell papers. Master thesis. Faculty of Virginia polytechnic Institute and State University. Blacksburg, USA.

12. Kohle H, Blick J, Poten W, Blaschek F \& Kauss W (1985). Chitosan-elicited callose synthesis in soy bean cells as a $\mathrm{Ca} 2+$ dependent process. Plant Physiology 77: 544-551.

13. Wani AM, Hussain PR, Meena RS \& Dar MA (2008). Effect of gamma irradiation and refrigerated storage on the improvement of quality and shelf life extension of pear (Pyrus communis L., Cv. Bartlett/ William). Rad Phy Chem 77: 983-989. 